\title{
Mechanisms of Oxidation and Vaporization of Antimony from Liquid Copper with CuCl-CaO Fluxes
}

\author{
Yang CUI, ${ }^{1)}$ Hiroyuki MATSUURA, ${ }^{2)}$ Tasuku HAMANO ${ }^{3)}$ and Fumitaka TSUKIHASHI ${ }^{21}$ \\ 1) Formerly Graduate Student, Department of Advanced Materials Science, Graduate School of Frontier Sciences, The \\ University of Tokyo. Now at Shougang Research Institute of Technology, Beijing, 100041, China. \\ 2) Department of Advanced Materials Science, Graduate School of Frontier Sciences, The University of Tokyo, 5-1-5 \\ Kashiwanoha, Kashiwa, Chiba 277-8561 Japan. \\ South Wales, Sydney, New South Wales 2052 Australia.
}

(Received on August 9, 2007; accepted on October 22, 2007)

In order to clarify the reaction mechanisms of oxidation and vaporization of $\mathrm{Sb}$ in liquid copper by using $\mathrm{CuCl}-\mathrm{CaO}$ fluxes, the vaporization behavior from $\mathrm{CuCl}-\mathrm{Sb}_{2} \mathrm{O}_{3}$ and $\mathrm{CuCl}-\mathrm{CaO}-\mathrm{Sb}_{2} \mathrm{O}_{3}$ fluxes and the reaction behavior of $\mathrm{Cu}_{2} \mathrm{O}$ between $\mathrm{CuCl}-\mathrm{Cu}_{2} \mathrm{O}$ flux and liquid copper were observed at $1423 \mathrm{~K}$ with argon gas.

For the vaporization from $\mathrm{CuCl}-\mathrm{Sb}_{2} \mathrm{O}_{3}$ and $\mathrm{CuCl}-\mathrm{CaO}-\mathrm{Sb}_{2} \mathrm{O}_{3}$ fluxes, $\mathrm{SbCl}_{3}$ and $\mathrm{SbOCl}$ in flux were observed in the fluxes, and these chloride and oxychloride vaporized to gas phase.

In the reaction between $\mathrm{CuCl}-\mathrm{Cu}_{2} \mathrm{O}$ and liquid copper, the decomposition of $\mathrm{Cu}_{2} \mathrm{O}$ in the flux was confirmed, and the copper weight and oxygen content of copper increased.

The mechanisms of oxidation and vaporization of antimony in liquid copper by using $\mathrm{CuCl}-\mathrm{CaO}$ fluxes were discussed based on the observed results. The $\mathrm{Cu}_{2} \mathrm{O}$ existing in $\mathrm{CuCl}-\mathrm{CaO}$ flux is dissolved in copper melt, and the oxygen content of copper increases. The antimony in liquid copper is oxidized and removed to slag phase as $\mathrm{Sb}^{3+}$. The formed $\mathrm{Sb}^{3+}$ in flux vaporizes from flux as $\mathrm{SbCl}_{3}$ and $\mathrm{SbOCl}$.

KEY WORDS: oxidation and vaporization mechanisms; antimony; copper scrap; chloride; oxychloride.

\section{Introduction}

Recently, the recycling of metal scrap becomes more and more important from the viewpoints of the efficient use of resources, environmental issues and energy saving. In Japan, about 600000 tons of copper scrap and about 30 million tons of steel scrap are recycled every year. ${ }^{1,2)}$ Copper next to steel and aluminum is massively produced to meet the social demand. Because copper ore has a short mining life of about 31 years, ${ }^{3)}$ the production of copper has to depend on the recycling of copper scrap in the future. In the recycling process of copper scrap, an important process is the removal of impurities such as $\mathrm{Sb}$ and $\mathrm{Pb}$ because these impurities affect not only the properties of copper such as the electric conductivity but also the environment. On the other hand, some removed impurities such as $\mathrm{Sb}$ used as the semiconductor and electrode materials should be recycled as resources.

The chlorination reaction with chlorine gas or chloride is utilized for the recycling of wastes such as aluminum scrap and steelmaking dust. ${ }^{4,5)}$ For the recycling of copper scrap, Tsukihashi and Hatta, ${ }^{6}$ and Iwasaki and Tsukihashi ${ }^{7)}$ reported that the partition ratios of $\mathrm{Fe}$ and $\mathrm{Pb}$ between $\mathrm{CuCl}$ based flux and liquid copper increased with increasing the content of $\mathrm{Na}_{2} \mathrm{CO}_{3}, \mathrm{CaO}$ or $\mathrm{BaO}$ in $\mathrm{CuCl}$ flux at $1473 \mathrm{~K}$, and a part of removed $\mathrm{Fe}$ and $\mathrm{Pb}$ vaporized to gas phase. Mochida and Mikuni ${ }^{8)}$ also reported that the concentration of $\mathrm{Fe}, \mathrm{Pb}, \mathrm{Zn}$ or $\mathrm{Sn}$ in copper largely decreased with time by using $\mathrm{Ar}-10 \% \mathrm{Cl}_{2}$ mixture at $1473 \mathrm{~K}$. Therefore, the chlorination reaction is effective for the removal of impurities from liquid copper.

In the previous study, ${ }^{9,10)}$ the present authors measured the removal rate of $\mathrm{Sb}$ from liquid copper by using $\mathrm{CuCl}-\mathrm{CaO}$ fluxes at $1423 \mathrm{~K}$ with argon gas. The removal of $\mathrm{Sb}$ from liquid copper was difficult by using only $\mathrm{CuCl}$ flux as shown in Eqs. (1) and (2). Equation (2) was obtained by the linear regression of calculated free energy change of reaction (1) from 1273 to $1673 \mathrm{~K}$ by FactSage. ${ }^{11)}$

$$
\begin{gathered}
\mathrm{Sb}(\mathrm{l})+3 \mathrm{CuCl}(\mathrm{l})=\mathrm{SbCl}_{3}(1)+3 \mathrm{Cu}(1) \ldots \ldots \ldots \ldots . . . \\
\Delta G_{1}^{\circ}=18380+35.1 T \mathrm{~J} / \mathrm{mol}^{11)}(1273-1673 \mathrm{~K}) . .
\end{gathered}
$$

However, the addition of $\mathrm{CaO}$ to $\mathrm{CuCl}$ flux was effective for the removal of $\mathrm{Sb}$. The concentration of $\mathrm{Sb}$ in liquid copper largely decreased with time and with increasing $\mathrm{CaO}$ content. About $99.9 \%$ of antimony was removed from liquid copper at $15 \mathrm{~min}$ by using $\mathrm{CuCl}-25$ mass $\% \mathrm{CaO}$ flux. Moreover, it was also confirmed that a part of antimony vaporized from flux to gas phase according to the mass balance. Compared with the reported $\mathrm{Na}_{2} \mathrm{CO}_{3}$ and $\mathrm{Cu}_{2} \mathrm{O}$-based fluxes, ${ }^{12,13)}$ the $\mathrm{CuCl}-\mathrm{CaO}$ fluxes have a high removal efficiency for $\mathrm{Sb}$ from liquid copper. For the $\mathrm{CuCl}-\mathrm{CaO}$ fluxes, the oxidation reaction of $\mathrm{Sb}$ in liquid copper may proceed the removal of antimony from liquid copper because the chlorination reaction of antimony by $\mathrm{CuCl}$ is difficult at $1423 \mathrm{~K}$. The source of oxygen for the oxidation reaction of 
$\mathrm{Sb}$ may be $\mathrm{Cu}_{2} \mathrm{O}$ existing in flux according to the measured weight change of metal and oxygen content of copper. Both of metal weight and oxygen content of metal increased with time and with increasing $\mathrm{CaO}$ content. The detailed mechanisms of oxidation and vaporization of $\mathrm{Sb}$ in liquid copper with $\mathrm{CuCl}-\mathrm{CaO}$ fluxes should be investigated.

The purpose of the present study is to clarify the mechanisms of oxidation and vaporization of $\mathrm{Sb}$ in liquid copper with $\mathrm{CuCl}-\mathrm{CaO}$ fluxes. The vaporization experiments of $\mathrm{CuCl}-\mathrm{Sb}_{2} \mathrm{O}_{3}$ and $\mathrm{CuCl}-\mathrm{CaO}-\mathrm{Sb}_{2} \mathrm{O}_{3}$ fluxes without liquid copper were carried out to investigate the vaporization behavior of $\mathrm{Sb}$ in flux, and the reaction behavior of $\mathrm{Cu}_{2} \mathrm{O}$ in $\mathrm{CuCl}-\mathrm{Cu}_{2} \mathrm{O}$ flux with liquid copper was observed to confirm the source of oxygen for the oxidation reaction of $\mathrm{Sb}$ in copper.

\section{Experimental}

For the vaporization experiments of $\mathrm{CuCl}-\mathrm{Sb}_{2} \mathrm{O}_{3}$ and $\mathrm{CuCl}-\mathrm{CaO}-\mathrm{Sb}_{2} \mathrm{O}_{3}$ fluxes at $1423 \mathrm{~K}$, about $1 \mathrm{~g}$ of flux prepared by mixing the reagent grade $\mathrm{CuCl}, \mathrm{Sb}_{2} \mathrm{O}_{3}$ and $\mathrm{CaO}$ calcined from $\mathrm{CaCO}_{3}$ at $1273 \mathrm{~K}$ was used. About $5 \mathrm{~g}$ of flux (Exp. Nos. 16, 17, 24 and 25) was vaporized for 30 or 60 min to collect the enough amount of dusts for the X-ray diffraction (XRD) analysis. The flux specimen was charged in an alumina crucible (outer diameter 21, inner diameter 17 and height $100 \mathrm{~mm}$ ). The crucible with flux was set in a porous magnesia protection crucible which was located in the hot zone of the mullite tube in an electric furnace. All experiments were carried out at $1423 \mathrm{~K}$ with the flow of dehydrated high purity argon (purity 99.999\%) of 250 $\mathrm{cm}^{3} / \mathrm{min}$. After the predetermined reaction time, the crucible was quickly taken out from the furnace and then quenched with flushing argon gas.

To observe the reaction behavior of $\mathrm{Cu}_{2} \mathrm{O}$ in $\mathrm{CuCl}-\mathrm{Cu}_{2} \mathrm{O}$ flux coexisting with liquid copper, the $\mathrm{CuCl}-\mathrm{Cu}_{2} \mathrm{O}$ flux was prepared by mixing the reagent grade $\mathrm{CuCl}$ and $\mathrm{Cu}_{2} \mathrm{O}$. Five grams of the flux and five grams of the high purity copper (purity 99.99\%) were charged in an alumina crucible. The used crucible, temperature, atmosphere and experimental procedure were the same as those of the vaporization experiments of $\mathrm{CuCl}-\mathrm{Sb}_{2} \mathrm{O}_{3}$ and $\mathrm{CuCl}-\mathrm{CaO}-\mathrm{Sb}_{2} \mathrm{O}_{3}$ fluxes.

Inductively Coupled Argon Plasma Atomic Emission Spectroscopy was used to analyze the compositions of $\mathrm{Cu}$, $\mathrm{Sb}$ and $\mathrm{Al}$. The Mohr method was applied for chlorine analysis. For the experiments on the reaction behavior of $\mathrm{Cu}_{2} \mathrm{O}$, the $\mathrm{LECO}$ combustion analyzer was used to determine the content of oxygen in copper. For the vaporization experiments of $\mathrm{CuCl}-\mathrm{Sb}_{2} \mathrm{O}_{3}$ and $\mathrm{CuCl}-\mathrm{CaO}-\mathrm{Sb}_{2} \mathrm{O}_{3}$ fluxes, some residues of fluxes and collected dusts were subjected to the XRD analysis. The basic data of JCPDS card (No. 60344, 5-0354, 11-689, 5-0667, 9-117, 1-0248, 21-52, 11$38,49-1092,28-775,1-1104,26-1053,20-209$ and 29-292) were used as reference.

\section{Results and Discussion}

\subsection{Vaporization Behavior of $\mathrm{Sb}$ from $\mathrm{CuCl}-\mathrm{Sb}_{2} \mathrm{O}_{3}$ and $\mathrm{CuCl}-\mathrm{CaO}-\mathrm{Sb}_{2} \mathrm{O}_{3}$ Fluxes at $1423 \mathrm{~K}$}

The vaporization experiments for $\mathrm{CuCl}-\mathrm{Sb}_{2} \mathrm{O}_{3}$ and $\mathrm{CuCl}-\mathrm{CaO}-\mathrm{Sb}_{2} \mathrm{O}_{3}$ fluxes were carried out to investigate the vaporization behavior of $\mathrm{Sb}$ in flux. The experimental conditions and results are shown in Table $\mathbf{1}$.

The weight of the system before and after the experiments was measured, and the weight loss was calculated. Figure 1 shows the change in weight loss of $\mathrm{CuCl}-\mathrm{Sb}_{2} \mathrm{O}_{3}$ fluxes with time at $1423 \mathrm{~K}$. The weight loss increases with time, and slightly decreases with increasing the content of $\mathrm{Sb}_{2} \mathrm{O}_{3}$ in flux. The $\mathrm{CuCl}$ and $\mathrm{Sb}_{2} \mathrm{O}_{3}$ easily vaporize as $\mathrm{CuCl}$, $\mathrm{Cu}_{3} \mathrm{Cl}_{3}$ and $\mathrm{Sb}_{4} \mathrm{O}_{6}$ at high temperature. The calculated vapor pressures of $\mathrm{CuCl}, \mathrm{Cu}_{3} \mathrm{Cl}_{3}$ and $\mathrm{Sb}_{4} \mathrm{O}_{6}$ are 0.0128, 0.803 and 0.0130 atm for the pure $\mathrm{CuCl}$ and $\mathrm{Sb}_{2} \mathrm{O}_{3}$ at $1423 \mathrm{~K}$, respectively. ${ }^{11)}$ Therefore, the weight loss of the system is mainly due to the simultaneous vaporization of $\mathrm{CuCl}$ and $\mathrm{Sb}_{2} \mathrm{O}_{3}$. Moreover, it is also possible that the antimony compounds such as $\mathrm{SbCl}_{3}$ vaporizes into gas phase.

Table 1. Experimental conditions and results for the vaporization experiments of flux.

\begin{tabular}{c|c|ccc|ccc|ccc}
\hline Exp. & Time & \multicolumn{3}{|c|}{ Initial composition $(\mathrm{g})$} & \multicolumn{3}{|c|}{ Final composition $(\mathrm{mass} \%)$} & \multicolumn{3}{|c}{ Weight loss $(\mathrm{g})$} \\
\cline { 3 - 11 } No. & $(\mathrm{min})$ & $\mathrm{Sb}_{2} \mathrm{O}_{3}$ & $\mathrm{CuCl}$ & $\mathrm{CaO}$ & $\mathrm{Cu}$ & $\mathrm{Sb}$ & $\mathrm{Al}$ & System & $\mathrm{Sb}$ & $\mathrm{CuCl}$ \\
\hline 1 & 8 & 0.999 & 0.117 & - & 7.714 & 72.66 & 0.729 & 0.151 & 0.123 & -0.001 \\
2 & 15 & 0.998 & 0.116 & - & 8.629 & 70.84 & 0.909 & 0.288 & 0.238 & 0.003 \\
3 & 20 & 0.999 & 0.116 & - & 9.321 & 69.35 & 1.07 & 0.374 & 0.310 & 0.006 \\
4 & 8 & 0.888 & 0.223 & - & 13.42 & 65.66 & 0.465 & 0.122 & 0.086 & 0.015 \\
5 & 15 & 0.889 & 0.222 & - & 13.93 & 64.79 & 0.669 & 0.252 & 0.179 & 0.033 \\
6 & 20 & 0.889 & 0.224 & - & 14.13 & 63.59 & 0.798 & 0.314 & 0.226 & 0.045 \\
7 & 8 & 0.367 & 0.747 & - & 45.00 & 25.36 & 0.051 & 0.181 & 0.070 & 0.092 \\
8 & 15 & 0.366 & 0.746 & - & 45.11 & 26.05 & 0.043 & 0.322 & 0.100 & 0.190 \\
9 & 20 & 0.366 & 0.746 & - & 45.15 & 26.88 & 0.153 & 0.409 & 0.116 & 0.250 \\
10 & 8 & 0.550 & 0.550 & - & 34.28 & 42.18 & 0.091 & 0.171 & 0.067 & 0.053 \\
11 & 15 & 0.550 & 0.550 & - & 34.74 & 44.96 & 0.298 & 0.310 & 0.103 & 0.120 \\
12 & 20 & 0.550 & 0.550 & - & 34.00 & 45.45 & 0.378 & 0.352 & 0.117 & 0.151 \\
13 & 8 & 0.221 & 0.880 & - & 56.61 & 14.14 & 0.081 & 0.141 & 0.048 & 0.032 \\
14 & 15 & 0.220 & 0.880 & - & 57.62 & 14.61 & 0.061 & 0.315 & 0.069 & 0.174 \\
15 & 20 & 0.221 & 0.879 & - & 60.49 & 14.42 & 0.070 & 0.408 & 0.085 & 0.226 \\
16 & 60 & 4.003 & 0.998 & - & - & - & - & 1.11 & - & - \\
17 & 60 & 0.999 & 4.002 & - & - & - & - & 1.35 & - & - \\
\hline 18 & 8 & 0.350 & 0.712 & 0.038 & - & - & - & 0.115 & - & - \\
19 & 15 & 0.350 & 0.714 & 0.038 & - & - & - & 0.200 & - & - \\
20 & 20 & 0.349 & 0.714 & 0.038 & - & - & - & 0.248 & - & - \\
21 & 8 & 0.324 & 0.660 & 0.117 & - & - & - & 0.056 & - & - \\
22 & 15 & 0.324 & 0.660 & 0.117 & - & - & - & 0.102 & - & - \\
23 & 20 & 0.324 & 0.661 & 0.117 & - & - & - & 0.128 & - & - \\
24 & 30 & 1.589 & 3.239 & 0.169 & - & - & - & 0.482 & - & - \\
25 & 30 & 1.470 & 3.001 & 0.527 & - & - & - & 0.235 & - & - \\
\hline & & & & & & & & & &
\end{tabular}




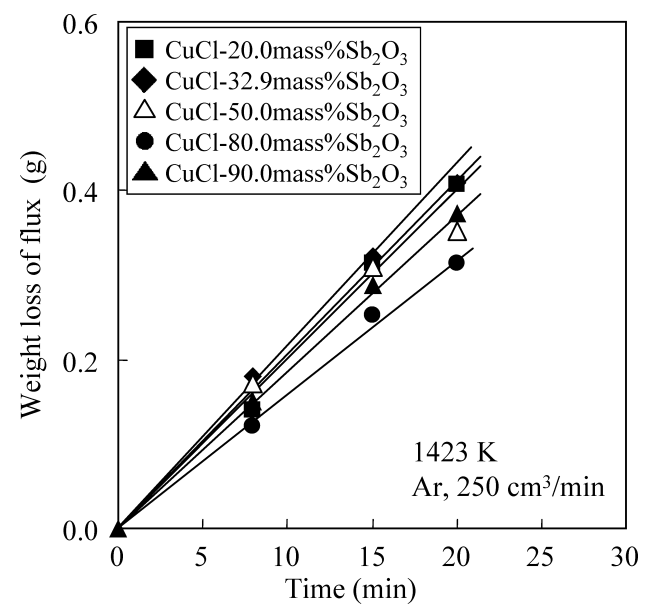

Fig. 1. Change in weight loss of $\mathrm{CuCl}-\mathrm{Sb}_{2} \mathrm{O}_{3}$ system with time.

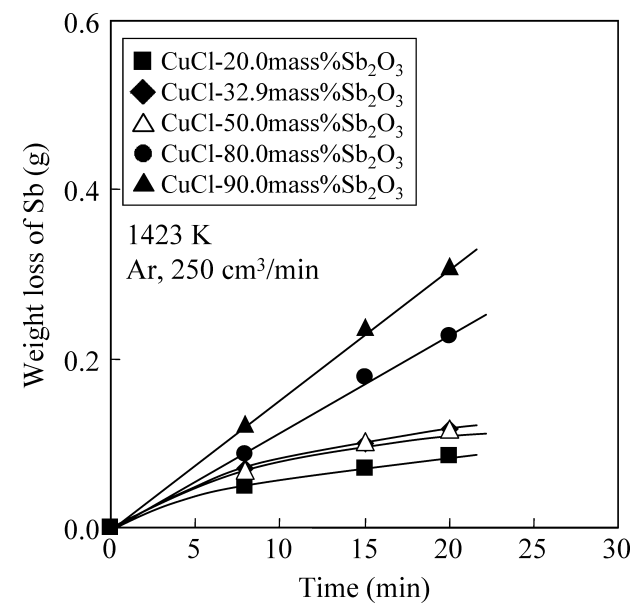

Fig. 2. Change in weight loss of $\mathrm{Sb}$ for $\mathrm{CuCl}-\mathrm{Sb}_{2} \mathrm{O}_{3}$ system with time.

The change in weight loss of Sb was also calculated according to the mass balance as shown in Eq. (3).

$$
W_{\mathrm{Sb}}^{\text {loss }}=W_{\mathrm{Sb}_{\text {in flux }}}^{0}-W_{\text {flux }}^{\mathrm{t}} \times \frac{(\operatorname{mass} \% \mathrm{Sb})}{100}
$$

where $W_{\text {Sbinflux }}^{0}, W_{\text {flux }}^{\mathrm{t}}$ and (mass $\% \mathrm{Sb}$ ) indicate the initial weight of $\mathrm{Sb}$, the final weight of flux and the final concentration of $\mathrm{Sb}$ in flux, respectively. Figure 2 shows the change in weight loss of $\mathrm{Sb}$ from $\mathrm{CuCl}-\mathrm{Sb}_{2} \mathrm{O}_{3}$ system with time at $1423 \mathrm{~K}$. The weight loss of $\mathrm{Sb}$ increases with time or with increasing the $\mathrm{Sb}_{2} \mathrm{O}_{3}$ content of flux. The weight loss of $\mathrm{Sb}$ is due to the vaporization of $\mathrm{Sb}_{2} \mathrm{O}_{3}$ and other antimony compounds such as $\mathrm{SbCl}_{3}$ and $\mathrm{SbOCl}$ according to the XRD analysis results in the following sections.

Figure 3 shows the change in weight loss of $\mathrm{CuCl}-\mathrm{CaO}-$ $\mathrm{Sb}_{2} \mathrm{O}_{3}$ fluxes with time at $1423 \mathrm{~K}$. The ratio of the initial content of $\mathrm{CuCl}$ to that of $\mathrm{Sb}_{2} \mathrm{O}_{3}$ was fixed at 2.04. The weight loss increases with time, and decreases with increasing the $\mathrm{CaO}$ content in flux. The decrease in the weight loss with the addition of $\mathrm{CaO}$ may be due to the decrease in the activity coefficient of $\mathrm{Sb}_{2} \mathrm{O}_{3}$ as acidic oxide because of the addition of $\mathrm{CaO}$ as basic oxide. ${ }^{13)}$ The weight loss of $\mathrm{Sb}$ from the $\mathrm{CuCl}-\mathrm{CaO}-\mathrm{Sb}_{2} \mathrm{O}_{3}$ system has not been estimated because of the difficulty of chemical analysis. The analysis results of collected dusts shown in Table 2 can qualitatively confirm the vaporization of $\mathrm{Sb}$ from flux though the col-

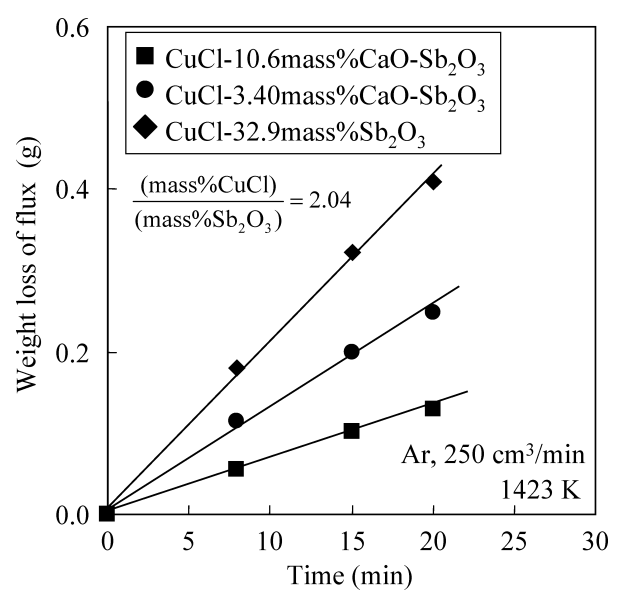

Fig. 3. Change in weight loss of $\mathrm{CuCl}-\mathrm{CaO}-\mathrm{Sb}_{2} \mathrm{O}_{3}$ system with time.

Table 2. Analysis results of collected dusts.

\begin{tabular}{c|c|c}
\hline Flux & Vaporization time (min) & mass $\% \mathrm{Sb}$ \\
\hline $\mathrm{CuCl}-10.6 \% \mathrm{CaO}-29.4 \% \mathrm{Sb}_{2} \mathrm{O}_{3}$ & 30 & 5.51 \\
\hline $\mathrm{CuCl}-3.40 \% \mathrm{CaO}-31.8 \% \mathrm{Sb}_{2} \mathrm{O}_{3}$ & 30 & 5.14 \\
\hline
\end{tabular}

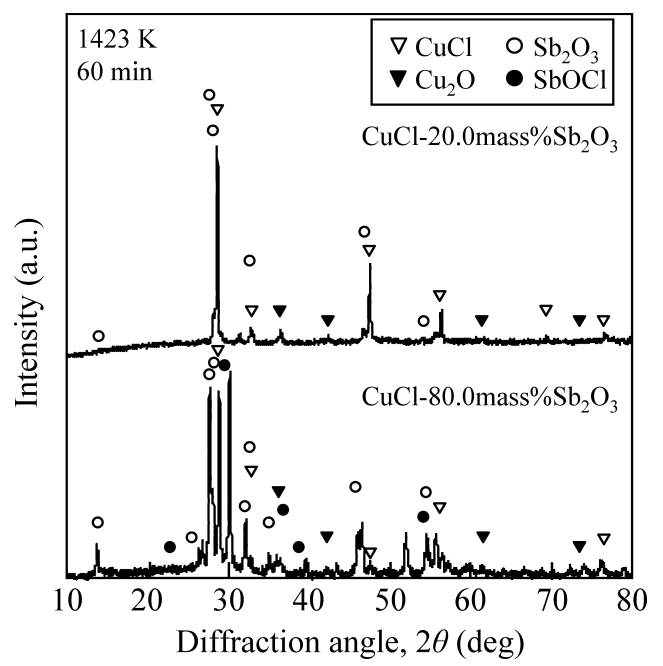

Fig. 4. XRD patterns of $\mathrm{CuCl}-\mathrm{Sb}_{2} \mathrm{O}_{3}$ fluxes after the vaporization reaction.

lected dusts also absorb water from air.

Figure 4 shows the XRD patterns of the vaporization residues from $\mathrm{CuCl}-80$ mass $\% \mathrm{Sb}_{2} \mathrm{O}_{3}$ (No. 16) and $\mathrm{CuCl}-$ 20 mass $\% \mathrm{Sb}_{2} \mathrm{O}_{3}$ (No. 17) fluxes for $60 \mathrm{~min}$. For $\mathrm{CuCl}-$ 80 mass $\% \mathrm{Sb}_{2} \mathrm{O}_{3}$ flux, the XRD peaks for antimony oxychloride, $\mathrm{SbOCl}$, and cuprous oxide, $\mathrm{Cu}_{2} \mathrm{O}$, were found. The XRD peaks for $\mathrm{Cu}_{2} \mathrm{O}$ were also found for $\mathrm{CuCl}-$ 20 mass $\% \mathrm{Sb}_{2} \mathrm{O}_{3}$ flux. It is considered that the observation of XRD peak corresponding to $\mathrm{Cu}_{2} \mathrm{O}$ indicates the affinity between $\mathrm{Cu}^{+}$and $\mathrm{O}^{2-}$ ions in liquid flux, though the XRD analysis of solidified flux may not represent the structure of liquid flux completely. Though the reactions expressed by Eqs. (4) and (5) were considered, Eq. (5) indicates that the reaction (4) is quite difficult to proceed. Nevertheless, the XRD peaks corresponding to $\mathrm{SbCl}_{3}$ were observed for corrected dusts and the reason for this fact has not been clarified yet. The formation of $\mathrm{SbOCl}$ in flux expressed as reaction (6) was also taken into consideration. The $\mathrm{SbCl}_{3}$ and $\mathrm{SbOCl}$ in flux may vaporize to gas as expressed by Eqs. (7) 


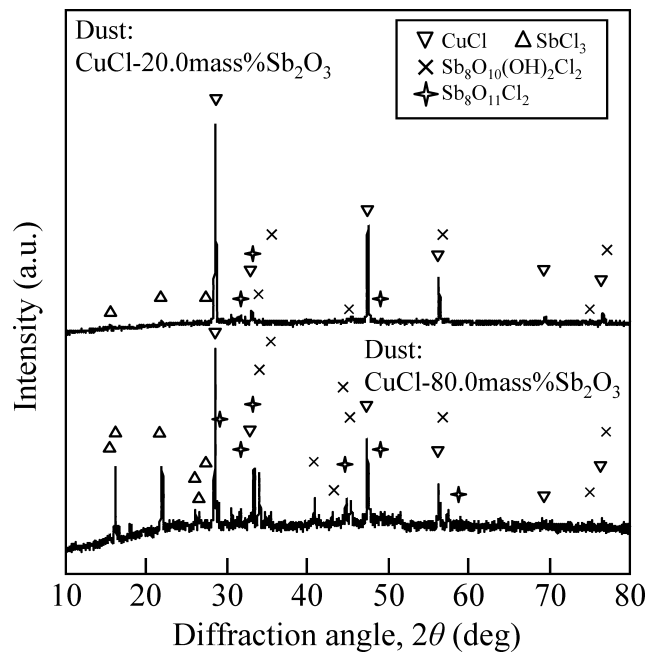

Fig. 5. XRD patterns of collected dusts from $\mathrm{CuCl}-\mathrm{Sb}_{2} \mathrm{O}_{3}$ fluxes.

to (9), if these species are thermodynamically preferable. The similar XRD analysis results for all samples shown in Table 1 were obtained. Equations (5) and (8) were obtained by the linear regression of calculated free energy changes of reactions (4) and (7) from 1273 to $1673 \mathrm{~K}$ by FactSage. ${ }^{11)}$

$$
\begin{aligned}
& \mathrm{Sb}_{2} \mathrm{O}_{3}(1)+6 \mathrm{CuCl}(\mathrm{l})=3 \mathrm{Cu}_{2} \mathrm{O}(1)+2 \mathrm{SbCl}_{3}(1) \ldots \ldots . .(4) \\
& \Delta G_{4}^{\circ}=312100+15.2 T \mathrm{~J} / \mathrm{mol}^{11)}(1273-1673 \mathrm{~K}) \ldots \\
& \mathrm{Sb}_{2} \mathrm{O}_{3}(1)+\mathrm{SbCl}_{3}(1)=3 \mathrm{SbOCl}(1) \text {.. } \\
& \mathrm{SbCl}_{3}(\mathrm{l})=\mathrm{SbCl}_{3}(\mathrm{~g}) \text {....... } \\
& \Delta G_{7}^{\circ}=3470-43.1 T \mathrm{~J} / \mathrm{mol}^{11)}(1273-1673 \mathrm{~K}) \text {...... } \\
& \operatorname{SbOCl}(1)=\operatorname{SbOCl}(\mathrm{g})
\end{aligned}
$$

Figure 5 shows the XRD patterns of collected dusts vaporized from $\mathrm{CuCl}-80$ mass $\% \mathrm{Sb}_{2} \mathrm{O}_{3}$ (No. 16) and $\mathrm{CuCl}-$ $20 \mathrm{mass} \% \mathrm{Sb}_{2} \mathrm{O}_{3}$ (No. 17) fluxes for $60 \mathrm{~min}$. The XRD peaks for $\mathrm{CuCl}, \mathrm{SbCl}_{3}$ and $\mathrm{Sb}_{8} \mathrm{O}_{11} \mathrm{Cl}_{2}$ were observed. The coexistence of $\mathrm{Sb}^{3+}$ and $\mathrm{Cl}^{-}$ions in the fluxes results in the vaporization of antimony chlorides or oxychlorides to gas phase. Binnewies and Schnockel ${ }^{14)}$ reported that the oxychloride $\mathrm{SbOCl}$ was formed in gas phase at $1300 \mathrm{~K}$ from the measurement by the mass spectroscopy combined with Knudsen cell according to the reaction (10). They also reported that the formed $\mathrm{SbOCl}$ was not stable in gas phase. Since $\mathrm{SbOCl}$ was confirmed in flux as shown in Fig. 4, the antimony may vaporize as $\mathrm{SbOCl}$ into gas phase as well as $\mathrm{Sb}_{4} \mathrm{O}_{6}$, and then $\mathrm{SbOCl}$ may react with $\mathrm{Sb}_{4} \mathrm{O}_{6}$ to form $\mathrm{Sb}_{8} \mathrm{O}_{11} \mathrm{Cl}_{2}$ in the solid state.

$$
2 \mathrm{SbCl}_{3}(\mathrm{~g})+\mathrm{O}_{2}(\mathrm{~g})+4 \mathrm{Ag}(\mathrm{l})=2 \mathrm{SbOCl}(\mathrm{g})+4 \mathrm{AgCl}(\mathrm{g})
$$

Figure 6 shows the XRD patterns of the vaporization residues from $\mathrm{CuCl}-3.40$ mass $\% \mathrm{CaO}-31.8$ mass $\% \mathrm{Sb}_{2} \mathrm{O}_{3}$ (No. 24) and CuCl-10.6mass\%CaO-29.4mass $\% \mathrm{Sb}_{2} \mathrm{O}_{3}$ (No. 25) fluxes for $30 \mathrm{~min}$. The XRD peaks for $\mathrm{SbOCl}$ and $\mathrm{Cu}_{2} \mathrm{O}$ were observed. Figure 7 shows the XRD patterns of collected dusts from the vaporization of these two fluxes. The XRD peaks for antimony chloride and antimony oxychlorides were observed, which suggests the vaporization of $\mathrm{Sb}$

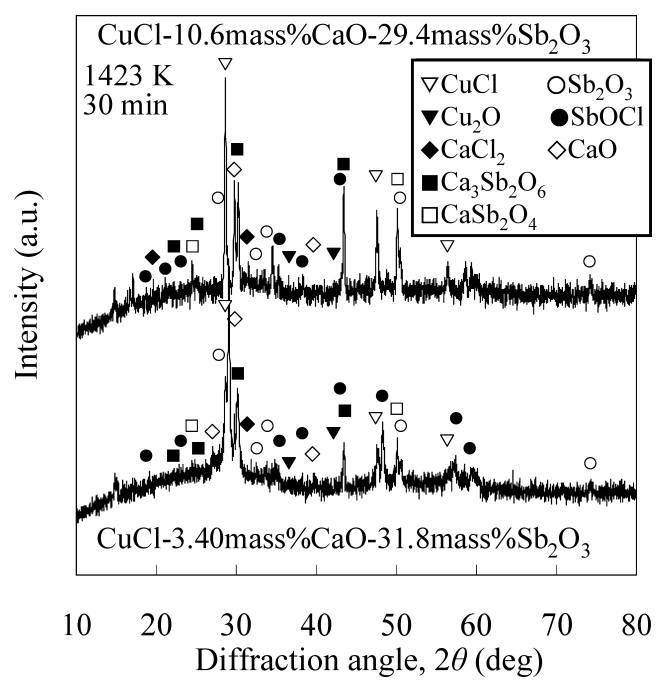

Fig. 6. XRD patterns of $\mathrm{CuCl}-\mathrm{CaO}-\mathrm{Sb}_{2} \mathrm{O}_{3}$ fluxes after the vaporization reaction.

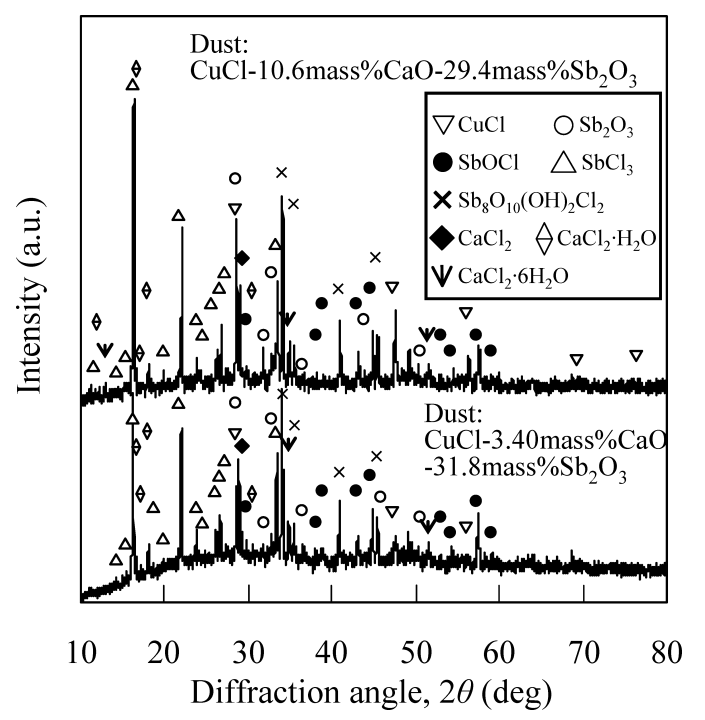

Fig. 7. XRD patterns of collected dusts from $\mathrm{CuCl}-\mathrm{CaO}-\mathrm{Sb}_{2} \mathrm{O}_{3}$ fluxes.

from flux as chloride and oxychloride.

\subsection{Reaction Behavior of $\mathrm{Cu}_{2} \mathrm{O}$ between $\mathrm{CuCl}-\mathrm{Cu}_{2} \mathrm{O}$ Flux and Liquid Copper at $1423 \mathrm{~K}$}

For the removal of $\mathrm{Sb}$ from liquid copper by using $\mathrm{CuCl}-\mathrm{CaO}$ fluxes at $1423 \mathrm{~K}, \mathrm{Sb}$ is considered to be removed by the oxidation reaction. In order to clarify the source of oxygen for oxidation, the reaction behavior of $\mathrm{Cu}_{2} \mathrm{O}$ between $\mathrm{CuCl}-\mathrm{Cu}_{2} \mathrm{O}$ flux and liquid copper was observed at $1423 \mathrm{~K}$. The initial contents of $\mathrm{Cu}_{2} \mathrm{O}$ were 0,3 and 6 mass $\%$. The experimental conditions and results are shown in Table 3.

The solubility of oxygen in copper equilibrated with solid $\mathrm{Cu}_{2} \mathrm{O}$ at $1423 \mathrm{~K}$ is 1.06 mass\% according to the phase diagram of $\mathrm{Cu}-\mathrm{O}$ system. ${ }^{15)}$ From the thermodynamic viewpoint, it can be confirmed that the $\mathrm{Cu}_{2} \mathrm{O}$ in flux decomposes into oxygen and copper at $1423 \mathrm{~K}$ as shown in Eqs. (11) and (12). Therefore, in this study the source of oxygen to oxidize $\mathrm{Sb}$ in copper may come from the dissolution of $\mathrm{Cu}_{2} \mathrm{O}$ existing in $\mathrm{CuCl}-\mathrm{CaO}$ flux to molten copper. 
Table 3. Experimental conditions and results for the reaction behavior of $\mathrm{Cu}_{2} \mathrm{O}$.

\begin{tabular}{c|c|c|cc|cc|c|ccc}
\hline \multirow{2}{*}{$\begin{array}{c}\text { Exp. } \\
\text { No. }\end{array}$} & Time & \multicolumn{2}{|c|}{ Initial composition $(\mathrm{g})$} & \multicolumn{3}{c|}{ Final composition $($ mass\%) } & \multicolumn{3}{c}{ Weight change $(\mathrm{g})$} \\
\cline { 3 - 11 } & $\mathrm{Cu}$ & $\mathrm{CuCl}$ & $\mathrm{Cu}_{2} \mathrm{O}$ & $\mathrm{Cu}_{\text {in flux }}$ & $\mathrm{Cl}_{\text {in flux }}$ & $\mathrm{O}_{\text {in metal }}$ & System & Flux & Metal \\
\hline 26 & 15 & 5.010 & 5.006 & - & 68.48 & 33.67 & 0.0829 & 0.371 & 0.351 & -0.020 \\
27 & 30 & 5.003 & 5.004 & - & 66.80 & 33.39 & - & 0.636 & 0.610 & -0.026 \\
28 & 45 & 5.008 & 5.004 & - & 64.61 & 32.52 & - & 0.858 & 0.844 & -0.014 \\
\hline 29 & 15 & 5.014 & 4.845 & 0.151 & 70.10 & 32.36 & 0.258 & 0.284 & 0.300 & 0.016 \\
30 & 15 & 5.013 & 4.702 & 0.302 & 65.06 & 31.61 & 0.381 & 0.254 & 0.326 & 0.072 \\
\hline
\end{tabular}

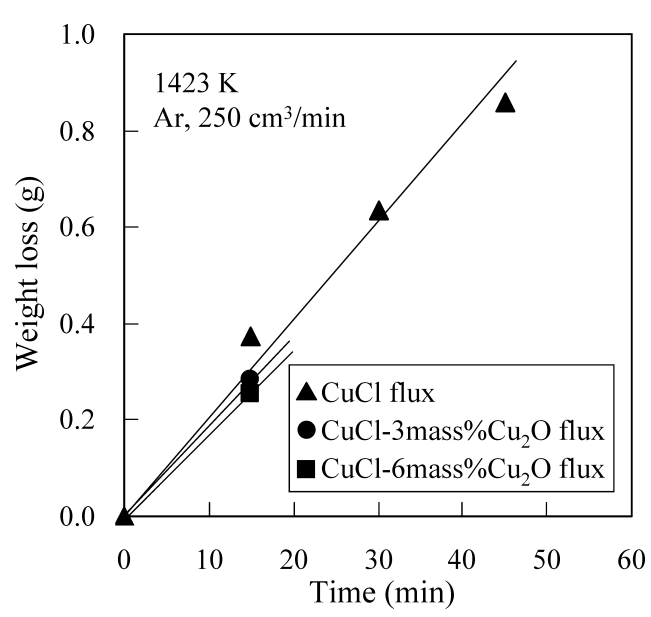

Fig. 8. Change in weight loss of $\mathrm{CuCl}-\mathrm{Cu}_{2} \mathrm{O}$ system with time.

$$
\begin{gathered}
\mathrm{CuO}_{0.5}(\mathrm{l})=\frac{1}{2} \underline{\mathrm{O}}(\operatorname{mass} \%)_{\text {in copper }}+\mathrm{Cu}(\mathrm{l}) \ldots \ldots . . \\
\Delta G_{11}^{\circ}=25840-18.0 T \mathrm{~J} / \mathrm{mol}^{11,16)}(1383-1693 \mathrm{~K}) \ldots .
\end{gathered}
$$

Figure 8 shows the change in weight loss of $\mathrm{CuCl}-\mathrm{Cu}_{2} \mathrm{O}$ system with time at $1423 \mathrm{~K}$. The weight loss increases with time, and slightly decreases with increasing the content of $\mathrm{Cu}_{2} \mathrm{O}$ in flux. The weight loss of the system is mainly due to the vaporization of $\mathrm{CuCl}$ from the flux.

Figure 9 shows the weight change of copper with time at $1423 \mathrm{~K}$. The measured oxygen contents of copper are also shown in this figure. The weight of copper coexisting with $\mathrm{CuCl}$ flux decreases with time and the molar ratio of $\mathrm{Cu}$ to $\mathrm{Cl}$ in flux is 1.12. For the $\mathrm{CuCl}-\mathrm{Cu}_{2} \mathrm{O}$ fluxes, both of copper weight and oxygen content of copper increase with increasing the $\mathrm{Cu}_{2} \mathrm{O}$ content. It can be confirmed that the increase in copper weight and oxygen content of copper is due to the dissolution of $\mathrm{Cu}_{2} \mathrm{O}$ existing in the $\mathrm{CuCl}-\mathrm{CaO}$ flux to molten copper. Therefore, the source of oxygen for the removal reaction of $\mathrm{Sb}$ by using $\mathrm{CuCl}-\mathrm{CaO}$ fluxes is $\mathrm{Cu}_{2} \mathrm{O}$ in flux as shown in Eqs. (11) and (12).

\subsection{Mechanisms of Oxidation and Vaporization of $\mathbf{S b}$ by Using $\mathrm{CuCl}-\mathrm{CaO}$ Fluxes at $1423 \mathrm{~K}$}

In the previous study, ${ }^{9,10)}$ it was reported that the removal of $\mathrm{Sb}$ from liquid copper was difficult by using only $\mathrm{CuCl}$ flux, while the addition of $\mathrm{CaO}$ to $\mathrm{CuCl}$ flux was effective for the removal of $\mathrm{Sb}$ at $1423 \mathrm{~K}$ with argon atmosphere. Moreover, a part of $\mathrm{Sb}$ vaporized from flux to gas phase. The oxidation reaction of $\mathrm{Sb}$ in liquid copper may proceed the antimony removal and the removed antimony vaporizes from flux as antimony chloride and oxychloride.

For the removal of $\mathrm{Sb}$ by using $\mathrm{CuCl}-\mathrm{CaO}$ fluxes at $1423 \mathrm{~K}, \mathrm{Cu}_{2} \mathrm{O}$ is formed by the reaction expressed by Eqs. (13) and (14). Equation (14) was obtained by the linear re-

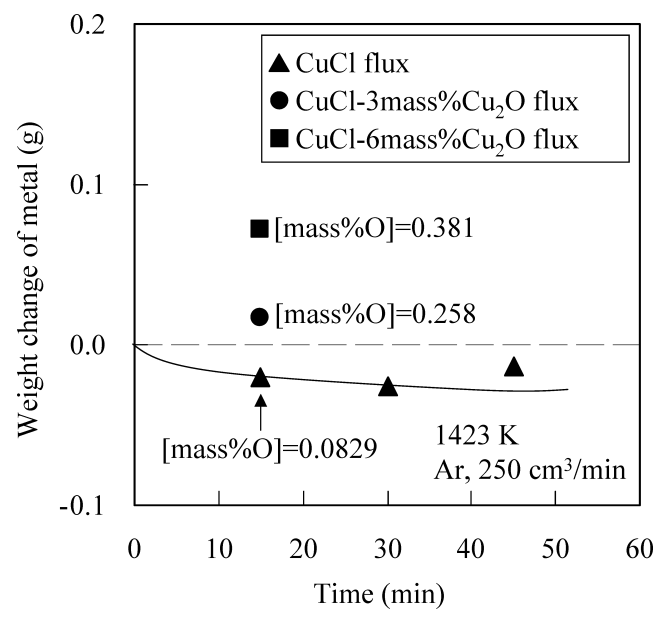

Fig. 9. Weight change of metal coexisting with $\mathrm{CuCl}-\mathrm{Cu}_{2} \mathrm{O}$ system with time.

gression of calculated free energy change of reaction (13) from 1273 to $1673 \mathrm{~K}$ by FactSage. ${ }^{11)}$ As described in the previous section, oxygen is supplied by the dissolution of $\mathrm{Cu}_{2} \mathrm{O}$ existing in the flux into liquid copper according to reaction (11), and oxidizes $\mathrm{Sb}$ in copper as shown in reaction (15). The overall oxidation reaction of $\mathrm{Sb}$ can be expressed by reaction (16). The addition of $\mathrm{CaO}$ increases $\mathrm{CaO}$ activity in the flux. Moreover, the oxygen content in copper also increases with increasing $\mathrm{CaO}$ content in the $\mathrm{CuCl}-\mathrm{CaO}$ fluxes. Therefore, the oxidation reaction of $\mathrm{Sb}$ in liquid copper can be accelerated because of the increase in $\mathrm{CaO}$ activity in the flux and the oxygen content in copper with increasing $\mathrm{CaO}$ content.

$$
\begin{aligned}
& \mathrm{CaO}(\mathrm{l})+2 \mathrm{CuCl}(\mathrm{l})=\mathrm{CaCl}_{2}(\mathrm{l})+\mathrm{Cu}_{2} \mathrm{O}(\mathrm{l}) \\
& \Delta G_{13}^{\circ}=-77260+26.4 T \mathrm{~J} / \mathrm{mol}^{11)}(1273-1673 \mathrm{~K}) \ldots \\
& \underline{\mathrm{Sb}}+\frac{3}{2} \underline{\mathrm{O}}=\mathrm{SbO}_{1.5}(1) \\
& 2 \underline{\mathrm{Sb}}+3 \underline{\mathrm{O}}+3 \mathrm{CaO}(\mathrm{s})=\mathrm{Ca}_{3} \mathrm{Sb}_{2} \mathrm{O}_{6}(\mathrm{~s})
\end{aligned}
$$

The removed antimony in flux may vaporize from flux as forms of $\mathrm{Sb}_{4} \mathrm{O}_{6}, \mathrm{SbCl}_{3}$ and $\mathrm{SbOCl}$ as expressed by reactions (4) to (9). In Sec. 3.1, the vaporization of $\mathrm{SbCl}_{3}$ and $\mathrm{SbOCl}$ from $\mathrm{CuCl}-\mathrm{Sb}_{2} \mathrm{O}_{3}$ and $\mathrm{CuCl}-\mathrm{CaO}-\mathrm{Sb}_{2} \mathrm{O}_{3}$ fluxes have been confirmed according to the XRD analysis results of collected dusts.

\section{Conclusions}

In order to clarify the mechanisms of oxidation and vaporization of $\mathrm{Sb}$ from liquid copper by using $\mathrm{CuCl}-\mathrm{CaO}$ fluxes, the vaporization behavior of $\mathrm{CuCl}-\mathrm{Sb}_{2} \mathrm{O}_{3}$ and $\mathrm{CuCl}-\mathrm{CaO}-\mathrm{Sb}_{2} \mathrm{O}_{3}$ fluxes and the reaction behavior of $\mathrm{Cu}_{2} \mathrm{O}$ between $\mathrm{CuCl}-\mathrm{Cu}_{2} \mathrm{O}$ flux and liquid copper were observed 
at $1423 \mathrm{~K}$ with argon atmosphere.

For the vaporization experiments of $\mathrm{CuCl}-\mathrm{Sb}_{2} \mathrm{O}_{3}$ and $\mathrm{CuCl}-\mathrm{CaO}-\mathrm{Sb}_{2} \mathrm{O}_{3}$ fluxes, antimony vaporized from fluxes as forms of $\mathrm{Sb}_{4} \mathrm{O}_{6}, \mathrm{SbCl}_{3}$ and $\mathrm{SbOCl}$.

For the reaction of $\mathrm{Cu}_{2} \mathrm{O}$ between $\mathrm{CuCl}-\mathrm{Cu}_{2} \mathrm{O}$ flux and liquid copper, the dissolution of $\mathrm{Cu}_{2} \mathrm{O}$ existing in flux was confirmed, and the copper weight and oxygen content of copper increased.

Based on the experimental results, the mechanisms of oxidation and vaporization of $\mathrm{Sb}$ by using the $\mathrm{CuCl}-\mathrm{CaO}$ fluxes were discussed. The $\mathrm{Cu}_{2} \mathrm{O}$ existing in $\mathrm{CuCl}-\mathrm{CaO}$ flux dissolved and resulted in an increase of oxygen content of copper. The antimony in liquid copper was oxidized and removed to flux. The antimony in flux vaporized as forms of $\mathrm{Sb}_{4} \mathrm{O}_{6}, \mathrm{SbCl}_{3}$ and $\mathrm{SbOCl}$ from flux.

\section{REFERENCES}

1) T. Okada, S. Ohyama, N. Katagiri, M. Shimada and S. Maeda: $J$. Min. Metall. Inst. Jpn., 113 (1997), 963.

2) F. Tsukihashi: CAMP-ISIJ, 17 (2004), 1460.

3) International Situation of Base Metals and the Change of Japan's Mineral Resources Policy, Japan Oil, Gas and Metals National Cor- poration (JOGMEC), Kanagawa, (2006), 1.

4) Q. Fu, D. Xu and J. W. Evans: Metall. Mater. Trans. B, 29B (1998), 971.

5) H. Matsuura, T. Hamano and F. Tsukihashi: ISIJ Int., 46 (2006), 1113.

6) F. Tsukihashi and T. Hatta: Proc. Tokyo Symp. on Recycling and Treatment of Metals, ed. by T. Nakamura and M. Maeda, The Center for Eco-Mining, Tokyo, (1997), 53.

7) H. Iwasaki and F. Tsukihashi: Proc. MMIJ Annual Meeting, (1998), 127.

8) H. Mochida and F. Mikuni: Proc. Tokyo Symp. on Recycling and Treatment of Metals, ed. by T. Nakamura and M. Maeda, The Center for Eco-Mining, Tokyo, (1997), 91.

9) Y. Cui, H. Matsuura, T. Hamano and F. Tsukihashi: CAMP-ISIJ, 19 (2006), 827.

10) Y. Cui, H. Matsuura, T. Hamano and F. Tsukihashi: Metall. Mater. Trans. B, 38B (2007), 485 .

11) CRCT-ThermFact Inc. and GTT-Technologies: FactSage 5.4, (2006).

12) M. Tanahashi, Z. J. Su, K. Takeda, H. Y. Sohn and C. Yamauchi: Metall. Mater. Trans. B, 34B (2003), 869.

13) Y. Cui, X. H. Du, T. Hamano and F. Tsukihashi: Mater. Trans., 47 (2006), 1540.

14) M. Binnewies and H. Schnockel: Chem. Rev., 90 (1990), 321.

15) H. Okamoto: Phase Diagrams for Binary Alloys, ASM Int., Materials Park, OH, (2000), 303.

16) A. D. Kulkarni: Metall. Trans., 4 (1973), 1713. 